\title{
Ocorrência de anticorpos anti-Toxoplasma gondii em ovinos das áreas urbanas e periurbanas de Curitiba, Paraná
}

\author{
Occurrence of anti-Toxoplasma gondii antibodies in ovine from \\ urban and periurban areas from Curitiba, Parana State \\ Vanete Thomaz Soccol ${ }^{1}$; Edilene A. de Castro ${ }^{1}$; Tatiana Louise Gazda ${ }^{1}$; Guilherme Garcia ${ }^{1}$; \\ Rosaria R. T. B. Richartz²; Rosangela Locatelli Dittrich ${ }^{3 *}$
}

${ }^{1}$ Departamento de Patologia Básica, Universidade Federal do Paraná - UFPR

${ }^{2}$ Centro de Diagnóstico Marcos Enrietti, Secretaria da Agricultura e do Abastecimento do Paraná - SEAB/PR

${ }^{3}$ Departamento de Medicina Veterinária, Universidade Federal do Paraná - UFPR

Recebido em 29 de Abril de 2008

Aceito em 26 de Maio de 2009

\section{Resumo}

Com o objetivo de avaliar a ocorrência da infecção por Toxoplasma gondii, em ovinos das regiôes periurbana e urbana do município de Curitiba, Paraná, Região Sul do Brasil, foram coletadas amostras de sangue de 167 ovinos, de três rebanhos. O teste de ELISA foi utilizado para detectar anticorpos anti-Toxoplasma gondii. Dos 167 soros ovinos, $43(25,75 \%)$ apresentaram anticorpos anti-T. gondii. O parasito está difundido entre os ovinos das duas regióes estudadas.

Palavras-chave: ELISA, toxoplasmose, ovinos, anticorpos.

\begin{abstract}
This study evaluated occurrence of the Toxoplasma gondii infection in ovine from urban and periurban areas of Curitiba, State of Paraná, Southern of Brazil. Blood samples from 167 sheep from three farms were collected. ELISA assay was used to detect IgG anti-Toxoplasma gondii antibodies. Of 167 ovine samples, 43 (25.75\%) were positive. The parasite is widespread among sheep from urban and periurban areas of Curitiba.
\end{abstract}

Keywords: ELISA, toxoplasmosis, sheep, antibodies.

Toxoplasma gondii é um protozoário coccídio, parasito intracelular obrigatório e de distribuição mundial. Os hospedeiros intermediários do T. gondii são vários vertebrados, principalmente aves e mamíferos, porém os únicos hospedeiros definitivos são os membros da família Felidae, que eliminam oocistos nas fezes, contaminam o ambiente e, consequentemente, humanos e outros animais (TENTER et al., 2000).

Os sinais clínicos da toxoplasmose nos animais são: febre, dispneia e sinais neurológicos. Os ovinos, suínos, caprinos e coelhos são mais comumente infectados por T. gondii do que bovinos e equinos. Em ovelhas, o parasito pode causar problemas reprodutivos, como abortamentos (DUBEY, 1990; TENTER et al., 2000).

A ingestão de cistos viáveis, presentes em carnes de animais infectados, é a via de transmissão mais importante para o ser humano. Portanto, o conhecimento da ocorrência da toxoplasmose em animais destinados ao consumo humano é de grande auxílio para a prevençáo dessa zoonose.

\footnotetext{
*Autor para correspondência: Rosangela Locatelli Dittrich

Departamento de Medicina Veterinária, Universidade Federal do Paraná - UFPR Rua dos Funcionários 1.540, Juveve, CEP 80035-050 Curitiba - PR, Brasil e-mail: roslocdi@ufpr.br
}

O objetivo do presente trabalho foi avaliar a ocorrência de anticorpos anti-Toxoplasma gondii, em ovinos da regiáo metropolitana de Curitiba, Paraná.

Foram coletadas amostras de sangue de 167 ovinos, sendo 91 pertencentes ao Centro de Estaçóes Experimentais do Canguiri da Universidade Federal do Paraná, em Pinhais, Paraná, área periurbana; 56 provenientes do Parque Barigui e 20 animais do Exército Brasileiro, de áreas urbanas de Curitiba. Os soros foram separados e armazenados a $-20^{\circ} \mathrm{C}$ até a análise sorológica.

O ensaio imunoenzimático indireto (ELISA) foi realizado segundo Engvall e Perlman (1972), com modificação no tempo de incubação (60 minutos para cada etapa). Foi utilizado antígeno solúvel de T. gondii, de taquizoítos obtidos de cultivo in vitro (cepa RH). O antígeno foi usado na concentraçáo de $500 \mathrm{ng} /$ poço da microplaca de 96 poços (Cornig ${ }^{\circ}$ ). As placas foram armazenadas a $4{ }^{\circ} \mathrm{C}$ durante 12 horas. No dia seguinte os poços foram lavados cinco vezes com tampão de lavagem $(8,5 \mathrm{~g}$ de $\mathrm{NaCl}, 0,32 \mathrm{~g}$ de fosfato de sódio monobásico $\left(\mathrm{NaH}_{2} \mathrm{PO}_{4}\right), 110 \mathrm{~g}$ de fosfato de sódio dibásico $\left(\mathrm{Na}_{2} \mathrm{HPO}_{4}\right), 1000 \mathrm{~mL}$ de água ultra pura e $\left.\mathrm{pH} 7,2\right)$. Em seguida foram adicionados $100 \mu \mathrm{L}$ de tampão de bloqueio (30 g albumina bovina - BSA), $1000 \mathrm{~mL}$ de PBS e $0,5 \mathrm{~mL}$ de "tween" 
Tabela 1. Ocorrência de anticorpos anti-Toxoplasma gondii, pelo ELISA, em três rebanhos ovinos das regiôes urbanas e periurbanas do município de Curitiba, Paraná, 2006.

\begin{tabular}{lccc}
\hline \multirow{2}{*}{ Origem } & \multicolumn{2}{c}{ Amostras } & $\begin{array}{c}\text { Ocorrência } \\
(\%)\end{array}$ \\
\cline { 2 - 3 } & Examinadas & Positivas & \\
\hline Regiáo periurbana & & & 17,6 \\
Fazenda Canguiri & 91 & 16 & \\
Regiáno urbana & & & \\
Aprisco Parque Barigui & 56 & 15 & 26,8 \\
Rebanho do Exército & 20 & 12 & 60 \\
Total & 167 & 43 & 25,75 \\
\hline
\end{tabular}

20, $\mathrm{pH} 7,4)$. As placas foram incubadas a $37^{\circ} \mathrm{C}$ por 90 minutos e em seguida procedeu-se a lavagem (seis vezes em lavadora automática) com tampão de lavagem.

As amostras de soro dos animais foram diluídas a 1:100 e 1:200 e a imunoglobulina $\mathrm{G}$ anti-ovino conjugada com peroxidase foi usada como conjugado (Sigma ${ }^{\circledast}$ ). A diluição foi determinada por titulação, de 1/1.000 até 1/10.000. Como substrato, foi usado o-fenilenodiamina, dicloridrato (OPD) $\left(0,38 \mathrm{mg} \cdot \mathrm{mL}^{-1} \mathrm{em}\right.$ tampáo citrato) e peróxido de hidrogênio como cromógeno $(4 \mu \mathrm{L}$ por $10,5 \mathrm{~mL}$ de tampão citrato).

Os soros controles positivos e negativos foram obtidos de animal infectado experimentalmente e animais recém-natos. Para calcular o nível de corte foram usados soros de 11 animais que apresentaram sorologia negativa pelo teste de imunofluorescência indireta (IFI), na diluiçáo de 1:20. O ponto de corte foi determinado como sendo a média das absorbâncias $(\omega)$ mais três desvios-padrão.

As diluiçóes do soro e do conjugado foram, respectivamente, de 1:100 e de 1:2.500, diferenciando os sororreagentes e não reagentes.

A soropositividade encontrada no presente estudo está apresentada na Tabela $1 . \mathrm{Na}$ área periurbana, 17,6\% dos animais apresentaram sorologia positiva. Nas áreas urbanas, 26,8 e 60\% dos ovinos apresentaram sorologia positiva. A ocorrência média de anticorpos para $T$. gondii foi de 25,75\% (43/167 ovinos).

As taxas de infecção para toxoplasmose, em rebanhos ovinos, são muito variáveis, em razão do método sorológico, da região do estudo, da idade e manejo dos animais (DUBEY, 1990). Neste estudo, a ocorrência média foi de $25,75 \%$, resultado semelhante aos de Gondim et al. (1999), com 18,75\% de ovelhas positivas na Bahia, aos de Meireles et al. (2003) e Figliuolo e Kasai (2004), que obtiveram ocorrências de 31 e 34,7\%, respectivamente, em ovinos do Estado de São Paulo. Em Pernambuco, Silva et al. (2003) detectaram 35,3\% de ovelhas soropositivas do total de 173 animais examinados.

Freire et al. (1995), Garcia et al. (1999) e Ogawa et al. (2003) verificaram soroprevalências de 47,8, 51,8 e 54,6\% para $T$. gondii em ovinos do norte do Paraná. Zonta et al. (1988), no Rio Grande do Sul, e Moura et al. (2007), no Paraná, verificaram baixas soroprevalências, de 18 e 7\%, respectivamente, correlacionando este achado ao sistema de criação extensivo.
Neste estudo, a ocorrência de anticorpos por propriedade variou de 17,6 a $60 \%$, demonstrando que o manejo dos animais e a presença de possíveis fatores de risco são fundamentais para a maior ou menor ocorrência do agente na propriedade. Toxoplasma gondii está presente nos ovinos da região metropolitana e periurbana de Curitiba, podendo ser esses animais possíveis fontes de infecção de T. gondii para os humanos.

\section{Referências}

DUBEY, J. P. Status of toxoplasmosis in sheep and goats in the United States. Journal of the American Veterinary Medical Association, v. 196, n. 2, p. 259-262, 1990.

ENGVALL, E.; PERLMANN, P. Enzyme Linked Immunosorbent Assay - ELISA. Journal of Immunology, v. 109, n. 1, p. 129-135, 1972.

FIGLIUOLO, L. P. C. et al. Prevalence of anti-Toxoplasma gondii and anti-Neospora caninum antibodies in ovine from São Paulo State, Brazil. Veterinary Parasitology, v. 123, n. 3/4, p. 161-166, 2004.

FREIRE, R. L. et al. Levantamento soroepidemiológico da toxoplasmose em ovinos da regiáo de Londrina - PR. Arquivo Brasileiro de Medicina Veterinária e Zootecnia, v. 47, n. 4, p. 609-612, 1995.

GARCIA, J. L. et al. Soroprevalência do Toxoplasma gondii, em suínos, bovinos, ovinos e eqüinos, e sua correlação com humanos, felinos e caninos, oriundos de propriedades rurais do Norte do Paraná-Brasil. Ciência Rural, v. 29, n. 1, p. 91-97, 1999.

GONDIM, L. F. P. et al. Serological survey of antibodies to Toxoplasma gondii in goats, sheep, cattle and water buffaloes in Bahia State, Brazil. Veterinary Parasitology, v. 82, n. 4, p. 273-276, 1999.

MEIRELES, L. R.; GALISTEO Jr., A. J.; ANDRADE Jr., H. F. Pesquisa sorológica de anticorpos anti-Toxoplasma gondii em animais de produção do Estado de São Paulo, Brasil. Brazilian Journal of Veterinary Research and Animal Science, v. 40, n. 4, p. 267-271, 2003.

MOURA, A. B. et al. Ocorrência de anticorpos contra Toxoplasma gondii em suínos e ovinos abatidos no município de Guarapuava, PR, Brasil. Revista Brasileira de Parasitologia Veterinária, v. 16, n. 1, p. 54-56. 2007.

OGAWA, L. et al. Ocorrência de anticorpos anti-Toxoplasma gondii em ovinos da regiâo de Londrina no Estado do Paraná. Semina: Ciências Agrárias, v. 24, n. 1, p. 57-62, 2003.

SILVA, A. V. et al. Toxoplasmose em ovinos e caprinos: estudo soroepidemiológico em duas regióes do Estado de Pernambuco, Brasil. Ciência Rural, v. 33, n. 1, p. 115-119, 2003.

TENTER, A. M.; HECKEROTH, A. R.; WEISS, L. M. Toxoplasma gondii: from animals to humans. International Journal of Parasitology, v. 30 , n. $12 / 13$, p. $1217-1258,2000$.

ZONTA, J. C. et al. Prevalência de anticorpos toxoplásmicos em ovinos de Marau e Uruguaiana, RS. Arquivo da Faculdade de Veterinária da UFRGS, v. 15/16, n. 1, p. 59-61, 1988. 